\title{
Can Pagoda Red staining be used for histopathological differentiation of canine allergic dermatitis?
}

\section{A coloração de Pagoda Red pode ser usada para diferenciação histopatológica de dermatites alérgicas caninas?}

\section{Tiago Cunha Ferreira ${ }^{1}$, Fábio Ranyeri Nunes Rodrigues ${ }^{2}$, Carlos Eduardo Bastos Lopes $^{3}$, Magna Gomes de Matos ${ }^{4}$, Diana Célia Sousa Nunes-Pinheiro ${ }^{5}$, Daniel de Araújo Viana $^{6 *}$}

\begin{abstract}
Allergic dermatopathies are pruritic cutaneous diseases often considered as diagnostic challenges due to the clinical similarity among its different types. On histopathological examination, a pattern of perivascular infiltrate composed of mononuclear cells and neutrophils can be identified in the four types of allergies. The marked presence of eosinophils suggests the division of the diseases into groups with small and large numbers of these cells, wich may be clearly evidenced through stains such as Pagoda Red. The objective of this work was to histologically characterize and quantify the eosinophils in skin of animals with allergic dermatitis. Histological slides from cutaneous biopsies of dogs with a suggestive clinical history of allergic dermatitis were selected and subdivided in two experimental groups according to the presence of eosinophils: group 1, animals with suspected canine atopic dermatitis or contact dermatitis (with little or none eosinophils), and group 2, animals suspected of ectoparasites allergy or food allergy. Pagoda Red staining was used in order to quantify eosinophils with a significant value of $p \leq 0.05$. The most prevalent epidermal changes in both groups were acanthosis and orthokeratosis. Perivascular infiltrate was composed of neutrophils, plasma cells, monocytes, lymphocytes and eosinophils. Regarding the quantification of eosinophils, there was a significant difference between the groups $(\mathrm{p}=$ 0.05). It was concluded that Pagoda Red staining allows quantification of eosinophils for differentiation of subtypes of allergic dermatitis in dogs, and may be used as an alternative easily accessible in the identification of eosinophils in canine allergic dermatitis.
\end{abstract}

Key-words: dog, skin, stain, diagnostic

Resumo: Dermatopatias alérgicas são doenças cutâneas pruriginosas, muitas vezes consideradas como desafios diagnósticos devido à similaridade clínica entre seus diferentes tipos. No exame histopatológico, um padrão de infiltrado perivascular composto por células mononucleares e neutrófilos pode ser identificado nos quatro tipos de alergias. A presença de eosinófilos sugere a divisão das doenças em grupos com pequenas e grandes quantidades dessas células, que podem ser claramente evidenciadas através de colorações como Pagoda Red. O objetivo deste trabalho foi caracterizar e quantificar histologicamente os eosinófilos na pele de animais com dermatite alérgica. Lâminas histológicas de biópsias cutâneas de cães com história clínica sugestiva de dermatite alérgica foram selecionadas e subdivididas em dois grupos experimentais de acordo com a presença de eosinófilos: grupo 1, animais com suspeita de dermatite atópica canina ou dermatite de contato (com pouco ou nenhum eosinófilo), e grupo 2, animais suspeitos de alergia a ectoparasitas ou alergia alimentar. A coloração Pagoda Red foi utilizada para quantificar eosinófilos com um valor significativo de 
$\mathrm{p} \leq 0,05$. As alterações epidérmicas mais prevalentes em ambos os grupos foram acantose e ortoqueratose. O infiltrado perivascular foi composto de neutrófilos, plasmócitos, monócitos, linfócitos e eosinófilos. Quanto à quantificação de eosinófilos, houve diferença significativa entre os grupos $(\mathrm{p}=0,05)$. Concluiu-se que a coloração de Pagoda Red permite a quantificação de eosinófilos para a diferenciação de subtipos de dermatite alérgica em cães e pode ser usada como alternativa facilmente acessível na identificação de eosinófilos em dermatite alérgica canina.

Palavras-chave: cão, pele, coloração, diagnóstico

Author for correspondence. E.Mail: *: viana_daniel78@gmail.com - Tel (85) 3034-4648 Recebido em 20.04.2017. Aceito em 30.09.2017

1 Student Veterinary Medicine Course, State University of Ceará - Campus Itaperi E-mail: tiagocf_@hotmail.com

2 Student Veterinary Medicine Course, State University of Ceará - Campus Itaperi E-mail: frnr.mv@gmail.com

3 Student Veterinary Medicine Course, State University of Ceará - Campus Itaperi E-mail: 1993carlos.eduardo@gmail.com

${ }^{4}$ Student Veterinary Medicine Course, State University of Ceará - Campus Itaperi E-mail: magnas570@gmail.com

${ }^{5}$ Doctor Professor, State University of Ceará - Campus Itaperi E-mail: csnpdiana@ hotmail.com

$6^{6 *}$ Doctor Professor, State University of Ceará, - Campus Itaperi, Legal Veterinary Medicine and Pathology Laboratory. Expedicionarios' Av., 5400, PATHOVET -Pathological Anatomy and Veterinary Clinical Pathology, Montese, Fortaleza/CE. Cep: 60410-234. E-mail: vianadanie178@gmail.com - Tel (85) 3034-4648

http://dx.doi.org/10.5935/1981-2965.20170026

\section{Introduction}

Allergic dermatopathies consist of pruritic cutaneous diseases resulting from immunological reactions to different types of antigens. Allergopathies, comprising ectoparasites allergy (EA), canine atopic dermatitis (CAD), food allergy (FA) and contact dermatitis (CD) (TIZARD, 2014), although common in veterinary clinical routine, represent a diagnostic challenge, since they have similar signs, hindering clinical diagnosis (CARDOSO et al., 2011).

Canine atopic dermatitis is an inflammatory, pruritic, and chronic disease, which pathogenesis involves an abnormal immune response with high

levels of $\operatorname{IgE}$ antibodies against allergens (type I hypersensitivity reaction), generating clinical signs such as erythema, itchiness and presence of opportunistic infections (HALLIWELL, 2006). Such immunopathogeny may also be observed in animals with FA and EA, sometimes by generating similar signs or even histopathological patterns. The first is defined as an immune-mediated reaction to antigens present in a particular diet or its additives, while the latter involves antigens contained in the saliva of flea and tick (MUKAI et al., 2002; WUERSCH et al., 2006). Additionally, those processes may 
occur at any age and sex (NASCENTE et al., 2006).

Another important differential diagnosis in allergic dermatitis is contact dermatitis, where the pathogenesis involves the type I and IV hypersensitivity reactions, requiring prolonged contact with the antigen for clinical manifestations (HO et al., 2015). Some of the allergens most commonly involved in such dermatopathy are actually particles of plastic materials, vegetables, detergents, waxes and carpets (JONES \& HORN, 2014).

The clinical signs observed in allergies mainly include pruritic cutaneous lesions, erythema, macules, papules, alopecia, excoriations, hyperpigmentation, lichenification and crusts. Bacterial and fungal secondary infections can also be identified, aggravating the lesion (TIZARD, 2014). The definitive diagnosis is generally based on anamnesis, clinical signs and exclusion of other pruritic skin diseases (HENSEL et al., 2015). However, it can be hampered due to similarity in symptomatology, jeopardizing the conduct adopted by the veterinarian.

On histopathological examination, a pattern of perivascular infiltrate composed of mononuclear cells and neutrophils can be identified in the four types of allergies. However, the marked presence of eosinophils suggests the division of these diseases in groups with small and large numbers of these cells (GROSS et al., 2005). This difference can be better evidenced by specific stains, such as Pagoda Red, a low-cost industrial dye, which major affinity is for eosinophils and mast cells when in organic tissues (BONETTI et. al., 2015).

From the above, this study aims to characterize the skin of animals affected by the different types of allergic dermatitis and to quantify the presence of eosinophils in an attempt to contribute to a most accurate histopathological differentiation of allergies.

\section{Material and methods}

\section{Ethical Aspects of Research}

The present study was submitted and approved by the Ethics Committee for the Use of Animals (CEUA) of the Universidade Estadual do Ceará, under the number 4720715/2016.

The samples were collected from archives and their use had no implications in changes of the routine examination or involved procedures. Samples were kept anonymous, exceptionally when new information generated could directly benefit the animal itself.

\section{Experimental groups}

Histological slides from cutaneous biopsies of dogs with a suggestive clinical history of allergy (single criterion of inclusion) were selected from the archives 
of a private diagnostic pathology breed did not constitute inclusion or exclusion criteria for this experiment.

After case selection, the slides were revised in order to be allocated in two experimental groups, taking as a distinguishing criterion the presence of eosinophils: group $1(\mathrm{n}=31)$, animals with suspected canine atopic dermatitis and contact dermatitis (with few or no eosinophils) and group $2(\mathrm{n}=31)$, animals with suspected EA or FA (with greater eosinophils presence).

\section{Histological analysis}

The slides were analyzed by optical microscopy (Nikon Eclipse E200®), where each tissue was evaluated for the presence of epidermal and dermal morphological changes and the results were presented in a descriptive way. In the epidermis, there were proliferative and degenerative lesions. In the dermis, the evaluation was focused on perivascular infiltrates, identifying the cell types, so as to enable a suggestive diagnosis of allergy.

\section{Quantitative eosinophil analysis}

For quantitative evaluation of eosinophils, special staining of Pagoda Red (TRANI et al., 2008) was performed. Histological sections of $5 \mu \mathrm{m}$ were bathed in xylene for 20 minutes and decreasing concentrations of alcohol and distilled water. Thereafter, the slides were laboratory between 2015/2016. Age, sex or immersed and a $1 \%$ solution of Red Pagoda, washed in distilled water and counterstained with hematoxylin-eosin for 1 minute. Dehydration was carried out, and the slides were mounted conventionally. Histological samples of eosinophilic granuloma (known as an eosinophil-rich tissue) were used as a control staining.

Quantitative analysis of eosinophils was performed under optical microscopy on a 100x objective, with 10 fields randomly displayed.

\section{Statistical analysis}

Data were presented as mean \pm standard deviation for inferences and general observations. The difference between groups was accessed through Student's T test, considering the result with $\mathrm{p} \leq 0.05$.

\section{Results}

A total of sixty-two cases of cutaneous biopsies of dogs with clinical suspect of allergy were selected: 31 with suspected CAD and CD (group 1) and 31 with suspected EA and FA (group 2).

The changes presented in the epidermis were acanthosis, orthokeratosis, parakeratosis and spongiosis (Figure 1), in varying degrees in groups 1 and 2. Table 1 shows the absolute and percentage values of each change in each of the analyzed groups. 
Ferreira et al., Revista Brasileira de Higiene e Sanidade Animal (v.11, n.3) p. 253 - 262, jan - mar (2017)

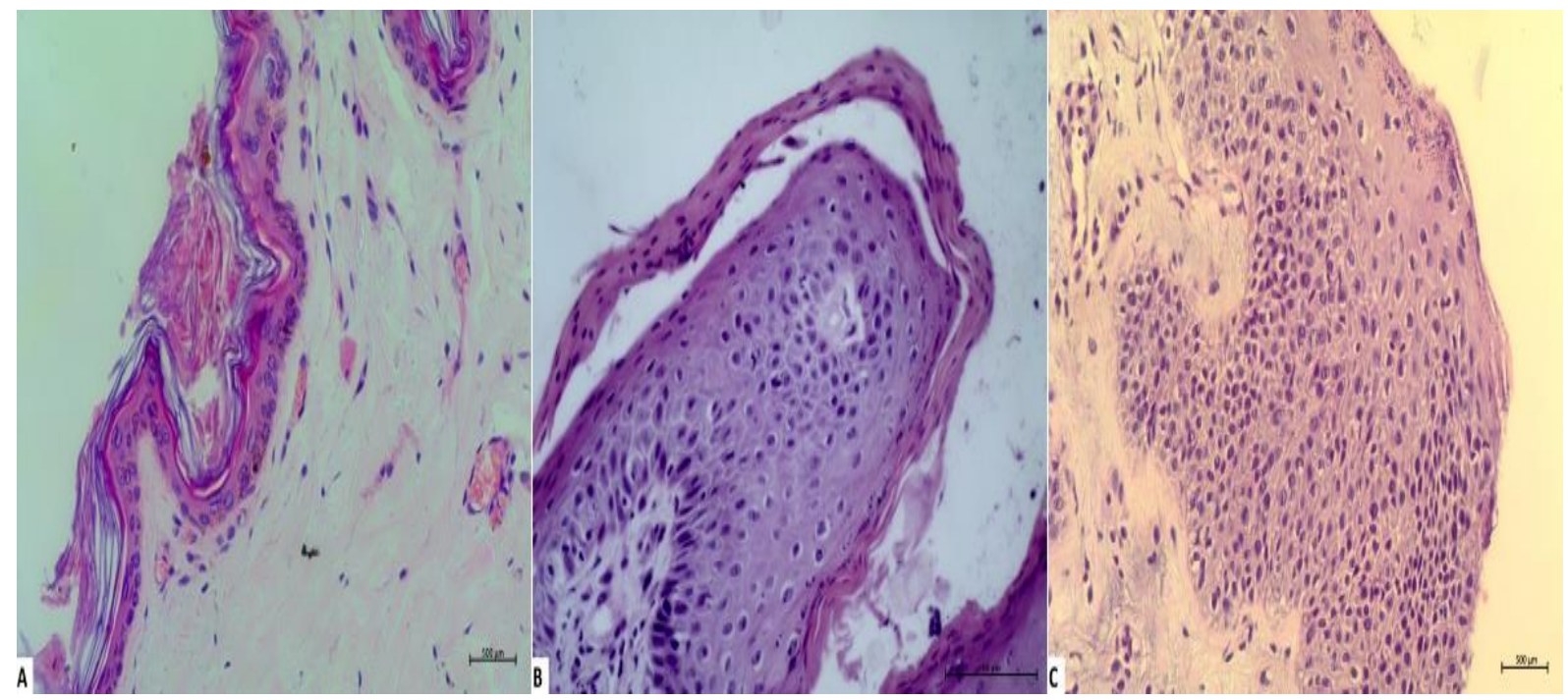

Figure 1 - Skin - Epidermal changes in the skin of allergic animals. (A) Orthokeratosis; (B) Parakeratosis; (C) Spongiosis. (HE, 200x).

The analysis of dermal alterations was restricted to the characterization of cellular infiltrate, whose absolute and percentage values are described in Table 1.

Table 1 - Absolute and relative values of alterations and inflammatory infiltrates observed in epidermis and dermis of allergic animals.

\begin{tabular}{|c|c|c|}
\hline \multirow{3}{*}{ Epidermal Alte } & \multirow{3}{*}{$\begin{array}{l}\text { Group } 1 \\
(n=31)\end{array}$} & \multirow{3}{*}{$\begin{array}{l}\text { Group } 2 \\
(n=31)\end{array}$} \\
\hline & & \\
\hline & & \\
\hline Acanthosis & $25 / 31(80,6 \%)$ & $26 / 31(83,8 \%)$ \\
\hline Orthokeratosis & $14 / 31(45,1 \%)$ & $13 / 31(41,9 \%)$ \\
\hline Parakeratosis & $5 / 31(16,1 \%)$ & $6 / 31(19,3 \%)$ \\
\hline Espongiosis & $6 / 31(19,3 \%)$ & $6 / 31(19,3 \%)$ \\
\hline \multicolumn{3}{|c|}{ Perivascular Inflammatory Infiltrate } \\
\hline Neutrophils & $8 / 31(25,8 \%)$ & $7 / 31(22,5 \%)$ \\
\hline Plasma Cells & $15 / 31(48,3 \%)$ & $22 / 31(70,9 \%)$ \\
\hline Monocytes & $27 / 31(87 \%)$ & $31 / 31(100 \%)$ \\
\hline Eosinophils & $15 / 31(48,3 \%)$ & $31 / 31(100 \%)$ \\
\hline Lymphocytes & $27 / 31(87 \%)$ & $31 / 31(100 \%)$ \\
\hline
\end{tabular}


Ferreira et al., Revista Brasileira de Higiene e Sanidade Animal (v.11, n.3) p. 253 - 262, jan - mar (2017)

The distribution of the inflammatory infiltrate was perivascular, composed of neutrophils, plasma cells, monocytes, lymphocytes and eosinophils in both groups, demonstrating variation in clearly less intense in group 1 when compared to group 2 (Figure 2). Eosinophils were present in $48.3 \%$ of cases in group 1 and in $100 \%$ of cases in group 2.

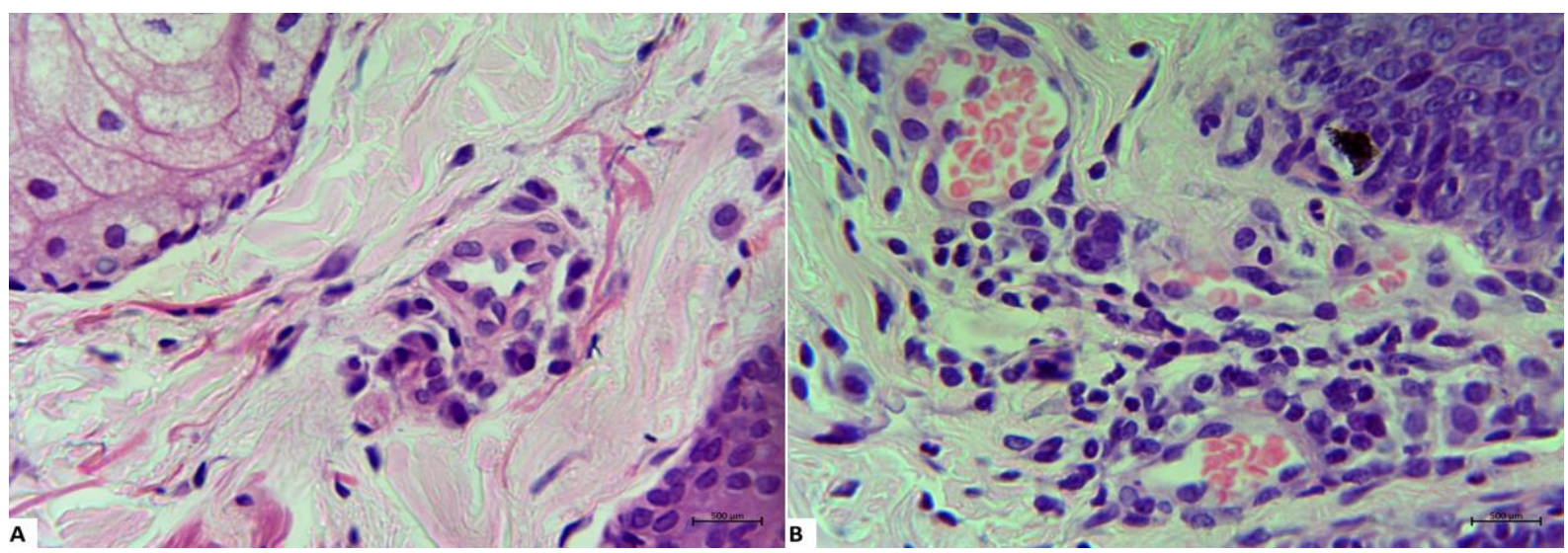

degree among cell populations, which was

Figure 2 - Skin - Dermis of allergic animals evidencing perivascular inflammatory infiltrate composed of neutrophils, plasma cells, monocytes, lymphocytes and eosinophils, less intense in group 1 (A) and more intense in group 2 (B). (HE, 200x)

The staining performed on both the control slides and each of the evaluated groups generated well-highlighted eosinophils with cytoplasm strongly stained from red to orange (Figure 3). There were no changes in color intensity between groups.

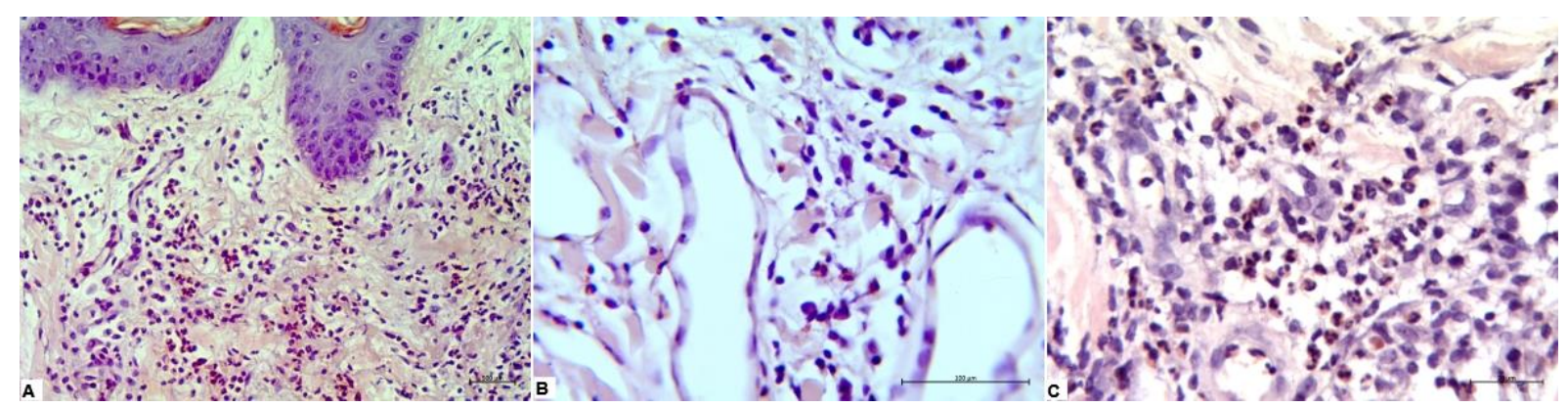

Figure 3 - Skin - Eosinophils in inflammatory infiltrate evidenced by Pagoda Red staining. (A) Positive Control of dye; (B) Group 1; (C) Group 2. (PR, 200x, 400x, 400x)

The quantitative evaluation of eosinophils through Pagoda Red staining is shown in Table 2. The first group presented a mean value of $5.73 \pm 9.15$ cells, while the second showed a mean value of $13.54 \pm 18.57$ cells, with $p=0.05$. 
Table 2 - Mean values and standard deviation of the number of eosinophils quantified through Pagoda Red staining in allergic animals.

\begin{tabular}{lcl}
\hline Eosinophil quantification & Group 1 $(\mathrm{n}=31)$ & Group $2(\mathrm{n}=31)$ \\
\hline Mean \pm SD & $5,73 \pm 9,15 \mathrm{a}$ & $13,54 \pm 18,57 \mathrm{~b}$ \\
& \\
\hline a-b indicate significant differences $(\mathrm{P} \leq 0,05)$.
\end{tabular}

\section{Discussion}

Allergic dermatitis is an inflammatory and pruritic disease, due to hypersensitivity reactions to various antigens (TIZARD, 2014). The clinical diagnosis is based on exclusion of different skin diseases from the history, clinical and laboratory findings. Allergenic and histopathological tests are also used routinely to support clinical suspicion (HENSEL et al., 2015). However, due to the similarity between histopathological patterns, its use becomes limited as a definitive diagnosis (CARLOTTI et al., 1990).

The histopathological lesions associated with $\mathrm{CAD}$ involve epidermal and dermal alterations. In epidermis, the most common findings involve parakeratotic and orthokeratotic hyperkeratosis, acanthosis, spongiosis and hypermelanosis. In dermis, there is presence of lymphocytes, monocytes, dendritic cells and eosinophils in perivascular areas (OLIVRY \& HILL, 2001). These lesion patterns can also be seen in $\mathrm{CD}$, making it difficult to differentiate it from CAD (NESBITT \& SCHMITZ, 1977; SAINT-MEZARD et al., 2004; LACHAPELLE \& MAROT, 2006; NOSBAUM et al., 2009).

In the present study, the groups were divided according to the characteristics of the inflammatory infiltrate, where group 1 was composed of animals whose infiltrate contained little or no eosinophils. This infiltrate is compatible with the histopathological description of CAD and CD (OLIVRY \& HILL, 2001; LACHAPELLE \& MAROT, 2006). The eosinophils were visualized in $48.3 \%$ of the cases, but the intensity of the infiltrate was slight, and quantitatively confirmed by the Red Pagoda dye. Epidermal findings were similar to those previously described (OLIVRY \& HILL, 
2001; LACHAPELLE \& MAROT, 2006). Acanthosis and orthokeratosis were the most prevalent alterations.

The epidermal and dermal histopathological findings of animals with EA or FA resemble those of the previous group, however, with a higher intensity of the infiltrate with greater presence of eosinophils (group 2), highlighting them as the main difference between the groups I and II.

Pagoda Red is a dye used in the textile industry, but in organic tissues it allows the observation of eosinophils and mast cells (TRANI et al., 2008). The differentiation between these cell types is performed through nuclear morphology. There are no reports in the literature about its use in allergic dermatitis in dogs. Furthermore, in this study, the dye was used to quantify eosinophils in canine allergic dermatopathies, with a significant difference between groups I and II, adding a new histopathological feature to the diagnosis of these diseases.

High numbers of eosinophils are common in type I hypersensitivity. These cells are attracted by stimuli from the mast cells and at the lesion site can act as effector cells of the allergic response (TIZARD, 2014). Eosinophils are granulocytes originated from bone marrow, and released into bloodstream in a phenotypically mature state, being capable of undergo tissue activation and chemotaxis in response to appropriate stimuli, by releasing IL-5 and eotaxin (HOGAN et al., 2008).

Although the immunopathogeny of allergic diseases involves the type I hypersensitivity reaction, it was noted that in group I, eosinophils were not strongly present in the infiltrate. This fact may be related to the difference in cellular mediators involved, affecting chemotaxis and eosinophilic function. It is also emphasized that atopic dermatitis is characterized by chronicity, where repeated allergic crises could influence the synthesis and secretion of different mediators of the immune response. However, studies using other biomarkers are needed in order to elucidate the actual participation of these cells in canine atopic dermatitis and contact dermatitis.

\section{Conclusion}

The Pagoda Red staining allows the quantification of eosinophils for the differentiation of subtypes of allergic dermatitis in dogs and can be used as an alternative easily accessible to identify eosinophils in canine allergic dermatitis. It is important to highlight that the better identification of eosinophils contributes to a better histopathological characterization, allowing the formation of subgroups with high and low numbers of these cells, which 
may influence the investigation of the factors triggering allergies in dogs, together with their prompt diagnosis.

\section{References}

1. BONETTI, L.R; MACCIO, L.; TRANI, N.,; RADHESHI, E.; PALMIERE, C. Splenic hypereosinophilia in anaphylaxisrelated death: different assessments depending on different types of allergens? International Journal of Legal Medicine, v. 129, p. 97-103, 2015.

2. CARDOSO, M. J.; MACHADO, L. H. A.; MELUSSI, M.; ZAMARIA, T. P.; CARNIELLI, C. M.; FERREIRA JÚNIOR, J. C. M. Dermatopatias em cães: 257 casos. Archives of Veterinary Science, v.16, n.2, p.66-74, 2011.

3. CARLOTTI, D.N.; REMY, I.; PROST, C. Food allergy in dogs and cats. A review and report of 43 cases. Veterinary Dermatology, v.1, p. 55-62, 1990.

4. GROSS, T. L.; IHRKE, P. J.; WALDER, E. J.; AFFORLTER, V. K. et al. Skin diseases of the dog and cat. Clinical and histopathologic diagnosis. 2nd. ed. Oxford: Blackwell, 2005. 932 p.

5. HALLIWELL, R.E.W. Revised nomenclature for veterinary allergy. Veterinary Immunology and Immunopathology, v.114, p.207-208, 2006.

6. HENSEL, P.; SANTORO, D.; FAVROT, C.; HILL, P.; GRIFFIN, C. Canine atopic dermatitis: detailed guidelines for diagnosis and allergen identification. BMC Veterinary Research, v.11, p.1-13, 2015.
7. HO, K.K.; CAMPBELL, K.L.; LAVERGNE, S.N. Contact dermatitis: a comparative and translational review of the literature. Veterinary Dermatology, v. 26, p.314-367, 2015.

8. HOGAN, S.P.; ROSENBERG, H. F.; MOGBEL, R.; PHIPPS, S.; FOSTER, P. S.; LACY, P.; KAY, A. B.; ROTHENBERG, M. E. Eosinophils: biological properties and role in health and disease. Clinical \& Experimental Allergy, v.38, p.709-750, 2008.

9. JONES, R., HORN, H.M. Identifying the causes of contact dermatitis. Practitioner, v.258, p.27-31, 2014.

10. LACHAPELLE; J.M., MAROT, L. Histopathological and immunohistopathological features of irritant and allergic contact dermatitis. In: FROSCH, P, MENN_E, T., LEPOITTEVIN, J-P., eds. Contact Dermatitis. Berlin/Heidelberg: Springer, p.107-116, 2006.

11. MARSELLA, R. Contact allergy. In: NOLI, C., FOSTER, A.P., ROSENKRANTZ, W., eds. Veterinary Allergy. Oxford: Wiley-Blackwell, p.183190, 2013.

12. MUKAI, L.S.; NETTO, A. C.; SZABO, M. P.; BECHARA, G. H. Hypersensitivity induced in dogs by nimphal extract of Amblyomma cajennense ticks (Acari: ixodidae). Annals of New York Academy of Sciences, v. 969, p.184-186, 2002.

13. NASCENTE, P.S.; XAVIER, M. O.; ROSA, C. S.; SOUZA, L. L.; MEIRELES, M. C. A.; MELLO, J. R. B. Hipersensibilidade alimentar em cães e gatos. Revista Clínica Veterinária, n.64, p.60-66, 2006. 
14. NESBITT, G.H.; SCHMITZ, J.A. Contact dermatitis in the dog: a review of 35 cases. Journal of American Animal Hospital Association, v.13, p.155-163, 1977.

15. NOSBAUM, A.; VOCANSON, M.; ROZIERES, A.; HENNINO, A.; NICOLAS, JF. Allergic and irritant contact dermatitis. European Journal of Dermatology, v.19, p.325-332, 2009.

16. OLIVRY, T.; HILL, P.B. The ACVD task force on canine atopic dermatitis (XVIII): histopathology of skin lesions. Veterinary Immunology and Immunopathology, v.81, p.305-309, 2001 .

17. SAINT-MEZARD, P.; ROSIERES, A.; KRASTEVA, M.; BERARD, F.; DUBOIS, B.; KAISERLIAN, D.; NICOLAS, JF. Allergic contact dermatitis. European Journal of Dermatology, v.14, p.284295, 2004.

18. TIZARD, I.R. Imunologia veterinária: Introdução. 9. ed. São Paulo: Elsevier, 533p., 2014.

19. TRANI, N.; BONETTI, L. R.; GUALANDRI, G.; BARBOLINI, G. Immediate anaphylactic death following antibiotics injection: Splenic eosinophilia easily revealed by pagoda red stain. Forensic Science International, v. 181, p.21-25, 2008.

20. WUERSCH K.; BRACHELENTE, C.; DOHERR, M.; REIST, M.; SATTLER, U.; FORSTER, U.; BERTONI, G.; PEEL,. J. E.; WELLE, M. Immune dysregulation in flea allergy dermatitis - a model for the immunopathogenesis of allergic dermatitis.

Veterinary Immunology and Immunopathology, v. 110, 311-323, 2006. 